\title{
Evaluation of mefenoxam and fludioxonil for control of \\ Rhizoctonia solani, Pythium ultimum and Fusarium solani on \\ cowpea
}

\author{
Tshekgene M Ramusi ${ }^{1,3}$, Jacquie E van der Waals ${ }^{1}$, Nico \\ Labuschagne $^{1}$ and Theresa AS Aveling ${ }^{1,2 *}$
}

\footnotetext{
${ }^{1}$ Department of Plant Science, University of Pretoria, Pretoria, South Africa, ${ }^{2}$ Forestry and Agricultural Biotechnology Institute (FABI), University of Pretoria, Pretoria, South Africa,

${ }^{3}$ Agricultural Research Council-Grain Crops Institute, Potchefstroom, South Africa

* Corresponding author, email: terry.aveling@fabi.up.ac.za
}

Cowpea (Vigna unguiculata) is susceptible to pathogens such as Rhizoctonia solani, Pythium ultimum and Fusarium solani causing seedling diseases in cowpea, resulting in low yields. Three commercial synthetic fungicides containing mefenoxam $350 \mathrm{~g}$ ai $\mathrm{L}^{-1}$, mefenoxam $240 \mathrm{~g}$ ai $\mathrm{L}^{-1}$ and fludioxonil $100 \mathrm{~g}^{\text {ai }} \mathrm{L}^{-1}$, respectively, were evaluated against these pathogens on cowpea in the greenhouse following promising in vitro results. The fungicides were applied initially as a soil drench to seedling trays at planting and fortnightly as a drench according to manufacturer's recommendations. All fungicides, except mefenoxam $350 \mathrm{~g}$ ai $\mathrm{L}^{-1}$ in one trial, were able to reduce diseases caused by $R$. solani. With the exception of mefenoxam $350 \mathrm{~g}$ ai $\mathrm{L}^{-1}$ in $F$. solani, all fungicides increased seedling emergence, and dry shoot and root mass of plants and all fungicide treatments reduced disease of seedlings grown in $F$. solani and $P$. ultimum 
inoculated growth medium. Although all three fungicides reduced the percentage of diseased seedlings, none of them gave complete control of the diseases caused by the three pathogens under the trial conditions.

Keywords: damping-off, fludioxonil, mefenoxam, seedling diseases, Vigna unguiculata.

\section{Introduction}

Cowpea (Vigna unguiculata L. Walp.) is widely grown in Africa and is also one of the most economically significant traditional legume crops because of its high protein content, ability to tolerate drought and to improve soil fertility (Valenzuela and Smith 2002; Langyintuo et al. 2003). Cowpea is susceptible to many pests and pathogens causing damage to the crop at all growth stages (Summerfield and Roberts 1985). Seedling diseases in cowpea result in low yields in rural areas where often no control measures are available against the diseases. Cowpea seedling diseases caused by Rhizoctonia spp., Pythium spp. and Fusarium spp. can result in great losses, particularly in the low altitude rain forests in countries such as Nigeria due to seed decay and seedling damping-off (Singh and Rachie 1985).

Chloroneb, tebuconazole, fludioxonil plus metalaxyl, carboxin, thiram and pyraclostrobin are some of the fungicides presently registered for the control of Rhizoctonia diseases (McMullen and Bradley 2005; BASF 2014). Fludioxonil can reduce disease incidence caused by Rhizoctonia root rot on ornamental plants, as reported by Martinez-Espinoza et al. (2004). Pythium spp. can be controlled 
by treating the soil with fungicides such as propamocarb-hydrochloride, etridiazole, metalaxyl and mefenoxam, as well as fumigation with a methyl bromide-chloropicrin combination (King and Parke 1993; Cordel et al. 2002). Mefenoxam is a fungicide that is generally known to be effective against oomycete pathogens such as Pythium spp. and Phytophthora spp. (Syngenta 2005). Fuchs and Himyck (2000); McMullen and Bradley (2005) and BASF (2014) reported control of Fusarium species using registered fungicides such as fludioxonil, captan, thiabendazole, tebuconazole, imazalil, thiophanate methyl and pyraclostrobin. Fludioxonil also controlled diseases caused by Fusarium spp. on maize (Munkvold and O'Mara 2002). McGovern et al. (2001) stated that mefenoxam could be used to control some Fusarium species on potted ornamentals. Kirk et al. (2013) also reported the effectiveness of mefenoxam against Fusarium pathogens which caused dry rot disease of potatoes.

Little research has been done on control measures for seedling diseases of cowpea (Masangwa et al. 2013.). Therefore, the current research was conducted to evaluate the efficacy of three unnamed commercial fungicides containing mefenoxam $350 \mathrm{~g}_{\text {ai } \mathrm{L}^{-1}}$, mefenoxam $240 \mathrm{~g}$ ai $\mathrm{L}^{-1}$ and fludioxonil $100 \mathrm{~g}$ ai $\mathrm{L}^{-1}$, against Rhizoctonia solani Kühn, Pythium ultimum Trow and Fusarium solani (Mart.) Sacc. Although fludioxonil $100 \mathrm{~g}^{a} \mathrm{~L}^{-1}$ is mainly used as a seed treatment, the three fungicides were tested for effectivity as soil drenches at planting and at 14 and 28 days after planting. 


\section{Materials and methods}

\section{Fungi}

Rhizoctonia solani (UPGH122), Pythium ultimum (UPGH050) and Fusarium solani (UPGH112) isolated from cowpea, were obtained from the fungal collection of the Department of Microbiology and Plant Pathology at the University of Pretoria, situated at latitude: $25^{\circ} 45^{\prime} 6.94^{\prime \prime}$ S, longitude: $28^{\circ} 15^{\prime} 34.69^{\prime \prime} \mathrm{E}$, and at an elevation of 1380 above sea level. To sub-culture the pathogens a mycelial disc (5 mm diameter) from actively growing cultures of each fungus was placed in the center of $90 \mathrm{~mm}$ potato dextrose agar (PDA) (Merck, Johannesburg) Petri dishes. The cultures were incubated under fluorescent light at $25^{\circ} \mathrm{C}$ for 7 days before use.

\section{Fungicides}

Three commercial synthetic fungicides were supplied by Syngenta South Africa (Pty) Ltd.: mefenoxam $350 \mathrm{~g}$ ai $\mathrm{L}^{-1}$, mefenoxam $240 \mathrm{~g}$ ai $\mathrm{L}^{-1}$ and fludioxonil $100 \mathrm{~g}$ ai $L^{-1}$.

\section{In vitro study}

Potato dextrose agar was augmented with the various fungicides at the following rates: mefenoxam $350 \mathrm{~g}_{\text {ai L }} \mathrm{L}^{-1}$ at $0.21 \mathrm{ml} \mathrm{L}^{-1}$ medium, mefenoxam $240 \mathrm{~g} \mathrm{ai} \mathrm{L}^{-1}$ at $0.27 \mathrm{ml} \mathrm{L}^{-1}$ medium and fludioxonil $100 \mathrm{~g}$ ai $\mathrm{L}^{-1}$ at $0.25 \mathrm{ml} \mathrm{L}^{-1}$ medium. The media were then poured into Petri dishes $(90 \mathrm{~mm})$ and allowed to solidify. A mycelial disc (5 mm diameter) from a 7-day-old PDA culture of each of $R$. solani, F. solani 
and $P$. ultimum was placed in the center of the amended or unamended (control) PDA Petri dishes. Four replicates of 12 Petri dishes per treatment were used for each pathogen. The Petri dishes were incubated under fluorescent light at $25 \stackrel{\circ}{C}$ for 9 days. Mycelial growth (colony diameter) was recorded in millimetres on the third, sixth and the ninth day after inoculation. The experiment was repeated three times.

\section{Greenhouse trials}

Polystyrene seedling trays (128 cells; cell size 67 x $34 \mathrm{~mm}$; $60 \mathrm{~mm}$ deep) were filled with steam-pasteurised growth medium (Braaks Lawn Dressing; Rietfontein Kleinhoewes, Plot 61, Garsfontein Rd, Pretoria). One day before pathogen inoculation, the growth medium was drenched with tap water. Two mycelial discs (5 $\mathrm{mm}$ diameter) of each pathogen respectively were prepared as described above and placed at a depth of $20 \mathrm{~mm}$ in each cell of the seedling trays $24 \mathrm{~h}$ before planting the cowpea seeds.

Cowpea seeds (cv. Pietersburg Blue) were obtained from the Dry Bean Seed Producer's Organisation, Pretoria. Seeds were planted in the seedling trays which were then placed in a randomized block design in a greenhouse. Four replications were included per treatment, each replicate consisting of 56 plants. This also included two controls, which consisted of un-inoculated and inoculated growth medium. Temperature in the greenhouse was maintained at between 22 and $25{ }^{\circ} \mathrm{C}$ with daylight of $13 \mathrm{~h}$ and seedling trays were watered daily with tap water. The experiment was repeated three times.

Fungicides were applied as drench treatments to the growth medium at the

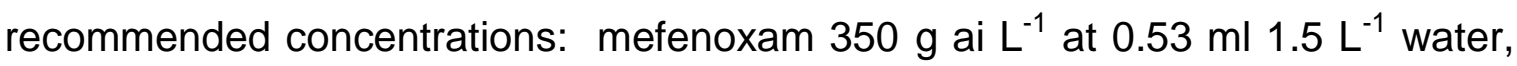


mefenoxam $240 \mathrm{~g}$ ai $\mathrm{L}^{-1}$ at $0.77 \mathrm{ml} 1.5 \mathrm{~L}^{-1}$ water and fludioxonil $100 \mathrm{~g} \mathrm{ai} \mathrm{L}^{-1}$ at $0.67 \mathrm{ml} 1.5 \mathrm{~L}^{-1}$ water. At planting the fungicides were applied to each seedling tray cell by means of a handheld sprayer until the surplus leached through. The applications were repeated at 14 and 28 days after planting. Plants were not watered on the day that they received chemical treatment to avoid leaching of the chemicals.

Percentage emergence and disease incidence were recorded at harvest on the $35^{\text {th }}$ day after planting. Shoot lengths were measured from seedling tip to the soil level a day before harvesting and averages calculated. The plants were harvested, roots were washed with tap water and disease symptoms on roots and shoots were recorded. Roots were then excised from the shoots with scissors, and roots and shoots were each placed separately into brown paper bags, dried for $48 \mathrm{~h}$ in a drying oven at $65{ }^{\circ} \mathrm{C}$ after which the dry mass of both roots and shoots were determined by weighing.

\section{Statistical analysis}

Two-way analysis of variance (ANOVA) was performed on all data and least significant differences $(P<0.05)$ were determined according to student $t$-test using MSTAT-C version 1.3 statistical program (Nissen 1983)

\section{Results}

\section{In vitro study}

All three fungicides viz. mefenoxam - $350 \mathrm{~g}$ ai $\mathrm{L}^{-1}$, mefenoxam $-240 \mathrm{~g}$ ai $\mathrm{L}^{-1}$ and fludioxonil -100 g ai $\mathrm{L}^{-1}$, applied at different concentrations, significantly reduced 
Table 1: Effect of fungicides on in vitro mycelial growth of Rhizoctonia solani, Fusarium solani and Pythium ultimum

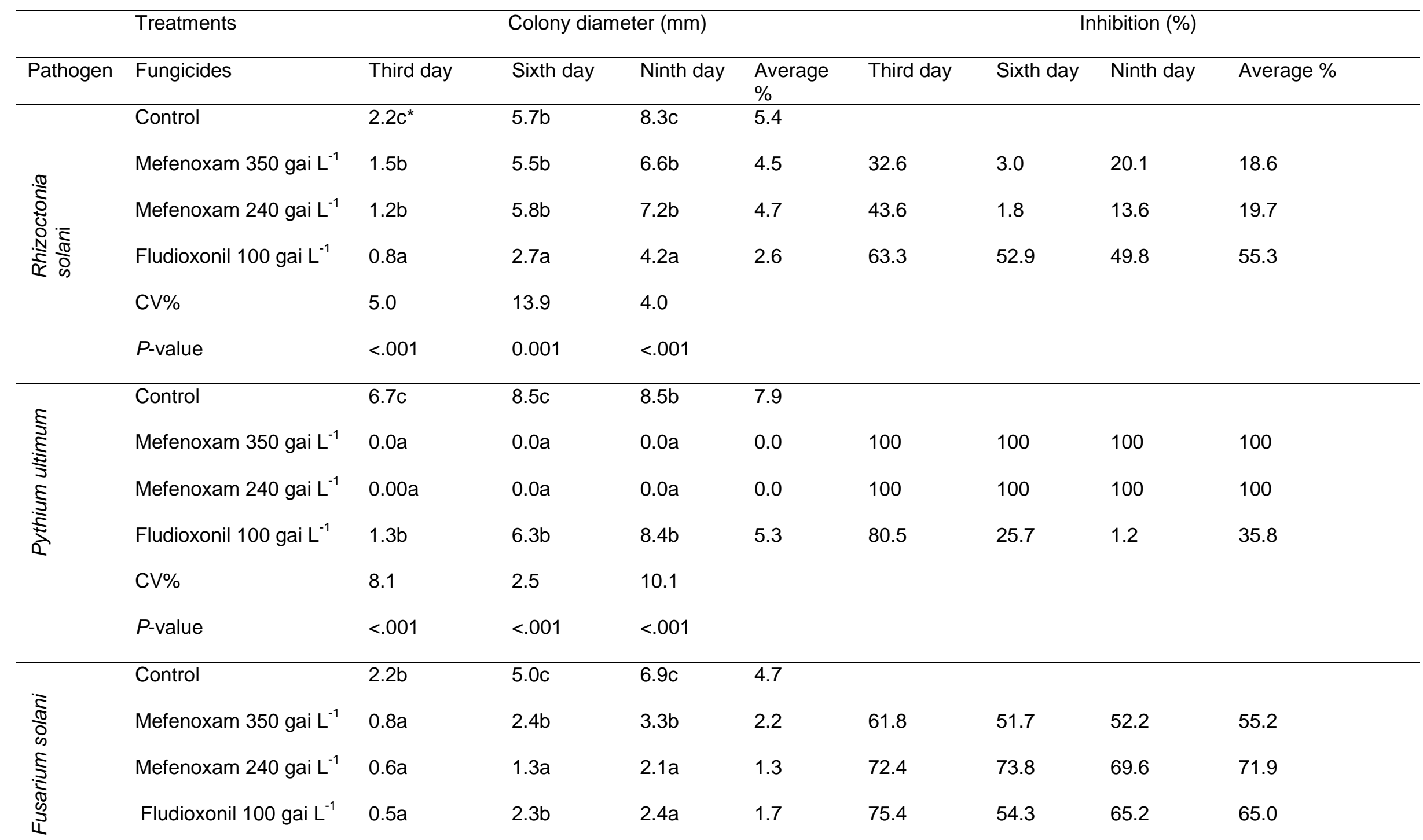




$\begin{array}{llll}\text { CV\% } & 16.9 & 4.8 & 7.1 \\ P \text {-value } & <.001 & <.001 & <.001\end{array}$

*Value is a mean of three replicates. Values in a column per pathogen followed by the same letter are not significantly different 
the mycelial growth of $R$. solani on the third and ninth day after the start of the experiment when compared to the control (Table 1). However, only fludioxonil 100 $g$ ai $L^{-1}$ was able to significantly inhibit mycelial growth of $R$. solanion the sixth day as opposed to the control. With the exception of fludioxonil $100 \mathrm{~g}$ ai $^{-1}$ on the ninth day, all fungicides significantly reduced mycelial growth of $P$. ultimum relative to the control (Table 1). All three fungicide treatments significantly reduced mycelial growth of $F$. solani throughout the experiment (Table 1).

\section{Greenhouse trials}

\section{Rhizoctonia solani}

In the first two trials application of mefenoxam $350 \mathrm{~g}^{a i} \mathrm{~L}^{-1}$ increased percentage seedling emergence, and plant height, dry shoot mass and dry root mass significantly, relative to the inoculated control. However, in trial three only percentage seedling emergence and plant height were increased significantly (Table 2). Mefenoxam $350 \mathrm{~g}_{\text {ai }} \mathrm{L}^{-1}$ was also found to have consistently reduced the percentage of diseased seedlings significantly in all three trials when compared to the inoculated control (Table 2). Although $R$. solani symptoms were observed on some of the harvested seedlings, application of mefenoxam $240 \mathrm{~g}$ ai $\mathrm{L}^{-1}$ reduced percentage of diseased seedlings in all three trials when compared to the inoculated control (Table 2). Application of mefenoxam $240 \mathrm{~g}_{\text {ai L }} \mathrm{L}^{-1}$ resulted in increased percentage seedling emergence, plant height, dry shoot mass and dry root mass compared to the inoculated control (Table 2). 
Table 2: Effect of fungicides on disease incidence, seedling emergence, plant height, dry shoot and dry root mass of cowpea in Rhizoctonia solani inoculated growth medium in the greenhouse.

\begin{tabular}{|c|c|c|c|c|c|c|}
\hline Treatment & $\begin{array}{l}\text { Seedling } \\
\text { emergence } \\
(\%)\end{array}$ & $\begin{array}{l}\text { Diseased } \\
\text { seedlings } \\
(\%)\end{array}$ & $\begin{array}{l}\% \\
\text { Reduction } \\
\text { in diseased } \\
\text { seedlings }\end{array}$ & $\begin{array}{l}\text { Plant height } \\
(\mathrm{cm})\end{array}$ & $\begin{array}{l}\text { Dry shoot } \\
\text { mass }(g)\end{array}$ & $\begin{array}{l}\text { Dry root } \\
\text { mass (g) }\end{array}$ \\
\hline \multicolumn{7}{|l|}{ Trial 1} \\
\hline Inoculated control & $21.5 a^{*}$ & $66.9 c$ & & $4.9 a$ & $5.3 a$ & $1.2 \mathrm{a}$ \\
\hline Uninoculated control & $64.0 \mathrm{c}$ & $0.0 \mathrm{a}$ & & $11.8 \mathrm{c}$ & $12.9 c$ & $4.9 c$ \\
\hline Mefenoxam 350 gai $L^{-1}$ & $41.8 \mathrm{~b}$ & $62.1 \mathrm{cb}$ & 4.9 & $7.6 b$ & $8.2 b$ & $3.4 b$ \\
\hline Mefenoxam 240 gai L ${ }^{-1}$ & $30.0 a b$ & $55 b$ & 12.0 & $5.6 a$ & $6.5 a b$ & $1.4 \mathrm{a}$ \\
\hline Fludioxonil 100 gai L $^{-1}$ & $39.5 b$ & $54.2 b$ & 12.8 & $7.7 \mathrm{~b}$ & $12.9 c$ & $4.9 \mathrm{c}$ \\
\hline CV\% & 21.4 & 27.9 & & 11.8 & 19.0 & 45.9 \\
\hline$P$-value & $<.001$ & $<.001$ & & $<.0011$ & $<.001$ & 0.002 \\
\hline \multicolumn{7}{|l|}{ Trial 2} \\
\hline Inoculated control & $49.3 a$ & $46.5 c$ & & $8.3 a$ & $7.6 a$ & $3.1 \mathrm{a}$ \\
\hline Un-inoculated control & $81.8 b$ & $0.0 \mathrm{a}$ & & $17.0 \mathrm{c}$ & $19.8 d$ & $9.2 \mathrm{c}$ \\
\hline 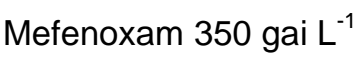 & $79.3 b$ & $18.8 b$ & 37.8 & $14.5 \mathrm{cb}$ & $13.8 b$ & $5.8 b$ \\
\hline Mefenoxam 240 gai L $^{-1}$ & $79.8 b$ & $25.0 \mathrm{~b}$ & 21.5 & $12.3 \mathrm{cb}$ & $14.4 \mathrm{cb}$ & $6.3 b$ \\
\hline Fludioxonil 100 gai L $^{-1}$ & $73.0 \mathrm{~b}$ & $17.8 b$ & 28.8 & $12.8 b$ & $14.1 b$ & $5.9 b$ \\
\hline CV\% & 8.0 & 22.4 & & 12.5 & 20.0 & 20.6 \\
\hline$P$-value & $<.001$ & $<.001$ & & $<.001$ & $<.001$ & $<.001$ \\
\hline \multicolumn{7}{|l|}{ Trial 3} \\
\hline Inoculated control & $33.0 \mathrm{a}$ & $79.7 c$ & & $4.1 \mathrm{a}$ & $3.9 a$ & $0.6 a$ \\
\hline Uninoculated control & $78.8 \mathrm{c}$ & $0.0 a$ & & $11.5 c$ & $14.4 d$ & $2.7 b$ \\
\hline 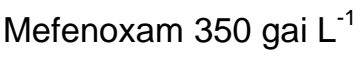 & $42.8 \mathrm{~b}$ & $31.3 b$ & 48.5 & $6.0 \mathrm{~b}$ & $4.2 \mathrm{a}$ & $0.5 \mathrm{a}$ \\
\hline Mefenoxam 240 gai L $^{-1}$ & $42.0 \mathrm{~b}$ & $39.6 b$ & 40.1 & $6.1 b$ & $6.4 b$ & $0.6 \mathrm{a}$ \\
\hline Fludioxonil 100 gai L $^{-1}$ & $40.8 b$ & $40.8 b$ & 38.9 & $4.5 \mathrm{a}$ & $6.9 \mathrm{cb}$ & $1.5 \mathrm{a}$ \\
\hline CV\% & 9.5 & 26.2 & & 9.3 & 21.8 & 58.0 \\
\hline$P$-value & $<.001$ & $<.001$ & & $<.001$ & $<.001$ & 0.001 \\
\hline
\end{tabular}

${ }^{*}$ Each value is a mean of four replicates of 56 seedlings. Values in a column followed by the same letter are not significantly different 
Application of fludioxonil $100 \mathrm{~g}$ ai L $^{-1}$ significantly reduced percentage of diseased seedlings caused by $R$. solani in all three trials when compared to the inoculated control (Table 2). Similar results were obtained from all three trials in which fludioxonil $100 \mathrm{~g}$ ai L $^{-1}$ significantly increased the percentage seedling emergence, plant height, dry shoot mass and dry root mass consistently, relative to the inoculated control (Table 2).

During harvesting it was observed in all the treatments that seeds which failed to germinate were brown and water-soaked. $R$. solani caused root rot and reddishbrown sunken lesions on the stem below and above the soil line (Fig. 1a).

\section{Pythium ultimum}

The percentage of diseased seedlings caused by $P$. ultimum was significantly reduced in all three trials following the application of mefenoxam $350 \mathrm{~g}$ ai L $^{-1}$ and mefenoxam $240 \mathrm{~g}$ ai $\mathrm{L}^{-1}$ (Table 3). Likewise, mefenoxam $350 \mathrm{~g}$ ai $\mathrm{L}^{-1}$ and mefenoxam $240 \mathrm{~g}$ ai $\mathrm{L}^{-1}$ significantly increased the percentage seedling emergence, plant height, and dry shoot mass in all three trials.

Fludioxonil $100 \mathrm{~g}_{\text {ai }} \mathrm{L}^{-1}$ significantly reduced the percentage of diseased seedlings caused by P. ultimum in all three trials when compared to the inoculated control (Table 3). In all three trials fludioxonil application caused an increase in percentage seedling emergence, plant height, dry shoot mass and dry root mass (Table 3). 
Table 3: Effect of fungicides on disease incidence, seedling emergence, plant height, dry shoot and dry root mass of cowpea in Pythium ultimum inoculated growth medium in the greenhouse.

\begin{tabular}{|c|c|c|c|c|c|c|}
\hline Treatment & $\begin{array}{l}\text { Seedling } \\
\text { emergence } \\
(\%)\end{array}$ & $\begin{array}{l}\text { Diseased } \\
\text { seedling } \\
(\%)\end{array}$ & $\begin{array}{l}\% \\
\text { Reduction } \\
\text { in diseased } \\
\text { seedlings }\end{array}$ & $\begin{array}{l}\text { Plant } \\
\text { height } \\
(\mathrm{cm})\end{array}$ & $\begin{array}{l}\text { Dry shoot } \\
\text { mass } \\
(\mathrm{g})\end{array}$ & $\begin{array}{l}\text { Dry root } \\
\text { mass } \\
\text { (g) }\end{array}$ \\
\hline \multicolumn{7}{|l|}{ Trial 1} \\
\hline Inoculated control & $41.1 \mathrm{a}^{*}$ & $60.3 c$ & & $3.6 a$ & $3.6 a$ & $1.4 \mathrm{a}$ \\
\hline Uninoculated control & $83.5 d$ & $0.0 \mathrm{a}$ & & $12.1 \mathrm{~d}$ & $19.5 d$ & $4.0 \mathrm{~d}$ \\
\hline Mefenoxam 350 gai L ${ }^{-1}$ & $62.7 \mathrm{cb}$ & $14.7 b$ & 45.5 & $9.8 \mathrm{c}$ & $12.6 \mathrm{bc}$ & $3.6 \mathrm{~cd}$ \\
\hline Mefenoxam 240 gai L ${ }^{-1}$ & $56.0 \mathrm{~b}$ & $13.9 b$ & 46.4 & $7.1 b$ & $9.4 b$ & $2.7 b$ \\
\hline Fludioxonil 100 gai L $^{-1}$ & $71.0 c$ & $10.7 b$ & 49.5 & $9.7 \mathrm{c}$ & $13.8 \mathrm{c}$ & $3.6 \mathrm{~cd}$ \\
\hline CV\% & 15.1 & 59.7 & & 16.7 & 26.4 & 26.0 \\
\hline$P$-value & $<.001$ & 0.014 & & $<.001$ & $<.001$ & 0.002 \\
\hline \multicolumn{7}{|l|}{ Trial 2} \\
\hline Inoculated control & $52.0 \mathrm{a}$ & $46.8 \mathrm{c}$ & & $9.5 a$ & $5.7 a$ & $1.5 \mathrm{a}$ \\
\hline Uninoculated control & $86.3 b$ & $0.0 \mathrm{a}$ & & $16.5 b$ & $16.8 d$ & $8.0 \mathrm{~d}$ \\
\hline Mefenoxam 350 gai L $^{-1}$ & $75.0 \mathrm{~b}$ & $19.0 \mathrm{~b}$ & 27.8 & $15.3 b$ & $12.8 \mathrm{c}$ & $4.0 \mathrm{c}$ \\
\hline Mefenoxam 240 gai L ${ }^{-1}$ & $82.3 b$ & $16.8 b$ & 30.1 & $13.8 \mathrm{~b}$ & $10.8 \mathrm{cb}$ & $4.4 \mathrm{c}$ \\
\hline Fludioxonil 100 gai L $^{-1}$ & $78.8 b$ & $16.8 \mathrm{~b}$ & 30.1 & $13.7 \mathrm{~b}$ & $9.6 b$ & $2.7 \mathrm{~b}$ \\
\hline CV\% & 5.2 & 24.3 & & 15.3 & 24.3 & 18.2 \\
\hline$P$-value & $<.001$ & $<.001$ & & 0.003 & $<.001$ & $<.001$ \\
\hline \multicolumn{7}{|l|}{ Trial 3} \\
\hline Inoculated control & $42.3 a$ & $68.3 d$ & & $4.8 \mathrm{a}$ & $7.9 a$ & $0.7 \mathrm{a}$ \\
\hline Uninoculated control & $77.3 c$ & $0.0 \mathrm{a}$ & & $10.7 d$ & $14.4 \mathrm{~b}$ & $3.0 \mathrm{bc}$ \\
\hline Mefenoxam 350 gai $L^{-1}$ & $53.0 \mathrm{~b}$ & $27.1 \mathrm{c}$ & 41.2 & $8.7 \mathrm{cb}$ & $8.9 a$ & $1.3 a b$ \\
\hline Mefenoxam 240 gai $L^{-1}$ & $50.3 a b$ & $22.9 c$ & 45.4 & $8.2 b$ & $7.0 \mathrm{a}$ & $0.9 a$ \\
\hline Fludioxonil 100 gai L $^{-1}$ & $46.0 \mathrm{ab}$ & $18.8 \mathrm{bc}$ & 49.6 & $7.7 \mathrm{~b}$ & $9.5 \mathrm{a}$ & $1.2 \mathrm{a}$ \\
\hline CV\% & 11.5 & 29.6 & & 9.6 & 17.0 & 41.9 \\
\hline$P$-value & $<.001$ & $<.001$ & & $<.001$ & $<.001$ & $<.001$ \\
\hline
\end{tabular}


In the P. ultimum inoculated treatments, some seeds failed to germinate and they were brown and water-soaked, whereas some seedlings showed symptoms of root rot and stunting. The basal part of the stems of these seedlings was soft and reduced in diameter when compared to the upper part of the stem (Fig. 1b).

\section{Fusarium solani}

Mefenoxam $350 \mathrm{~g}$ ai $\mathrm{L}^{-1}$ and mefenoxam $240 \mathrm{~g}_{\text {ai }} \mathrm{L}^{-1}$ significantly reduced the percentage of diseased seedlings in all three trials (Table 4). Similarly, in all three trials mefenoxam application caused an increase in seedling emergence, plant height, dry shoot mass and dry root mass compared to the inoculated control (Table 4). However, only results from the first and second trials indicated that mefenoxam $240 \mathrm{~g}_{\text {ai }} \mathrm{L}^{-1}$ increased the percentage seedling emergence, plant height, dry shoot mass and dry root mass compared to the inoculated control. Observations from the third trial indicated that there was decreased percentage seedling emergence, dry shoot mass and dry root mass relative to inoculated control (Table 4).

Application of fludioxonil $100 \mathrm{~g}$ ai $\mathrm{L}^{-1}$ significantly reduced percentage of diseased seedlings caused by $F$. solani in all three trials (Table 4). Likewise, results from all three trials showed increased percentage seedling emergence, plant height, dry shoot mass and dry root mass following application of fludioxonil $100 \mathrm{~g}_{\text {ai }} \mathrm{L}^{-1}$ relative to the inoculated control (Table 4). 
Table 4: Effects of fungicides on disease incidence, seedling emergence, plant height, dry shoot and root mass of cowpea in Fusarium solani inoculated growth medium in the greenhouse.

\begin{tabular}{|c|c|c|c|c|c|c|}
\hline Treatment & $\begin{array}{l}\text { Seedling } \\
\text { emergence } \\
(\%)\end{array}$ & $\begin{array}{l}\text { Diseased } \\
\text { seedlings } \\
(\%)\end{array}$ & $\begin{array}{l}\% \\
\text { Reduction } \\
\text { in diseased } \\
\text { seedlings }\end{array}$ & $\begin{array}{l}\text { Plant } \\
\text { height } \\
(\mathrm{cm})\end{array}$ & $\begin{array}{l}\text { Dry shoot } \\
\text { mass } \\
(\mathrm{g})\end{array}$ & $\begin{array}{l}\text { Dry root } \\
\text { mass } \\
\text { (g) }\end{array}$ \\
\hline \multicolumn{7}{|l|}{ Trial 1} \\
\hline Inoculated control & $44.3 a^{*}$ & $47.3 d$ & & $6.4 a$ & $8.9 a$ & $2.0 \mathrm{a}$ \\
\hline Uninoculated control & $64.8 b$ & $0.0 \mathrm{a}$ & & $9.5 \mathrm{c}$ & $15.7 b c$ & $6.6 c$ \\
\hline Mefenoxam 350 gai $L^{-1}$ & $59.3 a b$ & $12.6 b$ & 34.7 & $8.5 b c$ & $12.6 a b$ & $3.6 b$ \\
\hline Mefenoxam 240 gai $L^{-1}$ & $70.0 \mathrm{~b}$ & $17.7 \mathrm{bc}$ & 29.6 & $8.0 \mathrm{~b}$ & $17.7 \mathrm{c}$ & $3.4 b$ \\
\hline Fludioxonil 100 gai $\mathrm{L}^{-1}$ & $68.8 \mathrm{~b}$ & $17.4 \mathrm{bc}$ & 29.9 & $7.9 \mathrm{~b}$ & $17.4 \mathrm{c}$ & $3.9 b$ \\
\hline CV\% & 23.0 & 35.1 & & 9.4 & 24.7 & 22.8 \\
\hline$P$-value & $<.001$ & $<.001$ & & $<.001$ & 0.021 & $<.001$ \\
\hline \multicolumn{7}{|l|}{ Trial 2} \\
\hline Inoculated control & $45.8 \mathrm{a}$ & $58.50 d$ & & $8.750 a$ & $8.50 a$ & $1.93 a$ \\
\hline Uninoculated control & $82.3 b$ & $0.00 a$ & & $17.25 \mathrm{c}$ & $23.50 \mathrm{c}$ & $8.73 c$ \\
\hline 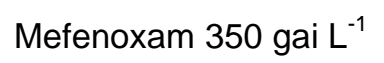 & $71.0 \mathrm{~b}$ & $18.25 \mathrm{cb}$ & 40.25 & $15.25 \mathrm{cb}$ & $9.00 \mathrm{cb}$ & $8.28 c$ \\
\hline Mefenoxam 240 gai $L^{-1}$ & $78.8 b$ & $12.00 \mathrm{~b}$ & 46.50 & $14.25 \mathrm{cb}$ & $15.75 b$ & $5.43 b$ \\
\hline Fludioxonil 100 gai L $^{-1}$ & $76.3 b$ & $13.50 \mathrm{~b}$ & 45.00 & $15.75 \mathrm{cb}$ & $16.00 \mathrm{~b}$ & $4.75 b$ \\
\hline CV\% & 14.0 & 27.7 & & 13.0 & 21.7 & 17.8 \\
\hline$P$-value & $<.001$ & $<.001$ & & $<.001$ & $<.001$ & $<.001$ \\
\hline \multicolumn{7}{|l|}{ Trial 3} \\
\hline Inoculated control & $42.8 \mathrm{a}$ & $64.8 \mathrm{c}$ & & $5.5 a$ & $5.9 a b$ & $0.6 a b$ \\
\hline Uninoculated control & $77.5 \mathrm{c}$ & $0.0 \mathrm{a}$ & & $11.1 d$ & $15.0 \mathrm{e}$ & $2.5 \mathrm{c}$ \\
\hline Mefenoxam 350 gai $L^{-1}$ & $52.3 b$ & $31.3 b$ & 33.5 & $9.0 \mathrm{c}$ & $10.7 d c$ & $2.6 c$ \\
\hline Mefenoxam 240 gai $L^{-1}$ & $53.0 \mathrm{~b}$ & $39.6 b$ & 25.2 & $8.6 \mathrm{cb}$ & $4.1 \mathrm{a}$ & $0.3 a$ \\
\hline Fludioxonil 100 gai L $^{-1}$ & 49.0ab & $33.3 b$ & 31.5 & $7.6 b$ & $8.2 \mathrm{bc}$ & $1.5 \mathrm{abc}$ \\
\hline $\mathrm{CV} \%$ & 9.6 & 37.0 & & 10.1 & 26.2 & 60.2 \\
\hline$P$-value & $<.001$ & $<.001$ & & $<.001$ & $<.001$ & $<.001$ \\
\hline
\end{tabular}


Small brown lesions were observed at harvesting on the roots of plants grown in F. solani inoculated growth media. Infected seedlings also showed symptoms of root rot. There was a reddish discolouration over the entire below ground stem and root system. Soft, dark brown or black cankers developed on the stem nodes and these often girdled the stem during disease development (Fig. 1c).

\section{DISCUSSION}

\section{In vitro study}

In this experiment we investigated the effect of mefenoxam $350 \mathrm{~g}$ ai $\mathrm{L}^{-1}$, mefenoxam $240 \mathrm{~g}_{\text {ai }} \mathrm{L}^{-1}$ and fludioxonil $100 \mathrm{~g}$ ai $\mathrm{L}^{-1}$ at different concentrations for inhibition of mycelial growth of three pathogens, namely, Pythium ultimum, Fusarium solani and Rhizoctonia solani. Mefenoxam at $350 \mathrm{~g} \mathrm{ai} \mathrm{L} \mathrm{L}^{-1}$ and mefenoxam at $240 \mathrm{~g}$ ai $\mathrm{L}^{-1}$ inhibited mycelial growth of all three pathogens. This fungicide is widely known to inhibit mycelial growth by interfering with the synthesis of ribosomal DNA (Syngenta 2014). Although mefenoxam gave better inhibition of $F$. solani when compared to fludioxonil, it is not widely known to be highly effective against the pathogen. However, Fravel et al. (2005) found mefenoxam to be effective in inhibiting the mycelial growth of Fusarium oxysporum, the causal fungus of wilt of tomatoes. Mefenoxam is known to be ineffective against Rhizoctonia, effective against Pythium and moderately effective 
against Fusarium (Syngenta 2014). The ability of fludioxonil $100 \mathrm{~g}_{\text {ai }} \mathrm{L}^{-1}$ to inhibit mycelial growth of $P$. ultimum, $F$. solani and $R$. solani was also investigated. Although the fungicide inhibited mycelial growth of all three pathogens in vitro, it is known to be ineffective against Pythium and intermediately effective against Rhizoctonia and Fusarium (Syngenta 2014). However, in similar studies, fludioxonil was reported to be effective in inhibiting mycelial growth of $R$. solani (Bucher and Pedersen 2004), P. ultimum (Errampalli 2004), and Fusarium spp. (Munkvold and O'Mara 2002; Wang et al. 2005; Solorzano and Malvick 2011). Based on our results the in vivo study was initiated to test the fungicides' ability to control seedling diseases of cowpea.

\section{Greenhouse trials}

This study showed that application of mefenoxam $350 \mathrm{~g}$ ai $\mathrm{L}^{-1}$ and mefenoxam $240 \mathrm{~g}$ ai $\mathrm{L}^{-1}$ as treatment fungicides against $R$. solani, $P$. ultimum and $F$. solani yielded positive results. The fungicides significantly reduced the percentage of diseased seedlings caused by all three pathogens in all three trials consistently. Of the seeds treated with mefenoxam $350 \mathrm{~g}$ ai $\mathrm{L}^{-1}$, mefenoxam $240 \mathrm{~g}$ ai $\mathrm{L}^{-1}$ and fludioxonil $100 \mathrm{~g}_{\text {ai }} \mathrm{L}^{-1}$ and planted in inoculated growth medium, the percentage of diseased seedlings in P. ultimum inoculated growth medium was the lowest followed by that of $F$. solani and $R$. solani. This is because mefenoxam $350 \mathrm{~g}^{\text {ai L }} \mathrm{L}^{-1}$ and mefenoxam $240 \mathrm{~g}_{\text {ai }} \mathrm{L}^{-1}$ contain a systemic fungicide which is known to be effective against seed and soil-borne pathogens such as Pythium and Phytophthora spp. (Syngenta 2014). Treatments with mefenoxam $350 \mathrm{~g}$ ai L ${ }^{-1}$ 
resulted in a reduction of $4.9,37.8$ and 48.5 percent diseased cowpea seedlings infected by $R$. solani in trial 1, 2 and 3, respectively, 45.5, 27.8 and 41.2 by $P$. ultimum and $34.7,40.3$ and 33.5 by $F$. solani, respectively. Whereas, mefenoxam $240 \mathrm{~g}_{\text {ai L }} \mathrm{L}^{-1}$ reduced percentage diseased cowpea seedlings by 12.0, 21.4 and $40.1 \%$ in $R$. solani inoculated growth medium in trial 1,2 and 3, respectively., 46.4, 30.1 and $45.4 \%$ in P. ultimum inoculated growth medium and 29.6, 46.5 and $25.2 \%$ in F. solani inoculated growth medium, respectively. Augusto et al. (2010) reported positive results on the effectiveness of mefenoxam against Pythium myriotylum. Its effectiveness against pathogens such as $F$. solani is not well known, however, Chang et al. (2013) screened Apron Maxx (mefenoxam) against F. avenaceum on pea and found that the fungicide consistently increased seedling emergence, nodulation, seed yield and reduced root rot severity. Kirk et al. (2013) also reported the effectiveness of mefenoxam in reducing dry rot incidence caused by Fusarium pathogens. Martinez-Espinoza et al. (2004) reported that mefenoxam is effective against Rhizoctonia solani of ornamental plants.

Mefenoxam $350 \mathrm{~g}$ ai $\mathrm{L}^{-1}$ and mefenoxam $240 \mathrm{~g}$ ai $\mathrm{L}^{-1}$ did not only significantly reduce the percentage of diseased seedlings caused by all three pathogens, but also increased the percentage seedling emergence, and plant height, dry shoot mass and dry root mass in all three trials. The average percentage seedling emergence in both $P$. ultimum and $F$. solani inoculated growth medium for all three trials increased to $64 \%$ relative to the inoculated control which was $45 \%$. Whereas for $R$. solani inoculated growth medium the percentage seedling emergence was higher (52\%) when compared to the 
inoculated control (35\%). When applied to the roots zone, mefenoxam is absorbed by the roots and transported through the xylem up the plant (Greencast 2014).

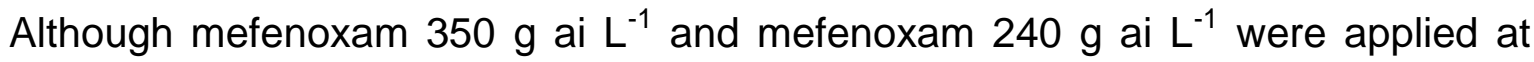
different concentrations, their effectiveness against all three pathogens did not differ much.

Fludioxonil $100 \mathrm{~g}_{\text {ai }} \mathrm{L}^{-1}$ reduced percentage diseased seedlings by 12.8 , 28.8 and $39.9 \%$ in the three $R$. solani greenhouse trials respectively, $49.5,30.1$ and $49.6 \%$ in the P. ultimum and $29.9,45.0$ and $31.5 \%$ in the $F$. solani greenhouse trials 1, 2 and 3, respectively. Likewise, application of fludioxonil 100 $\mathrm{g}$ ai $\mathrm{L}^{-1}$ also increased the percentage of seedling emergence, and plant height, dry shoot mass and dry root mass in all three trials relative to the inoculated control. These results are in agreement with the findings by Aveling et al. (2012) who, when investigating the effect of Celest $^{\circledR} \mathrm{XL}$ (mefenoxam and fludioxonil) against Fusarium graminearum, reported that it reduced the percentage of diseased maize seedlings. This fungicide is registered in South Africa for the control of seed- and soil-borne pathogens including Pythium spp. and Fusarium spp. (Syngenta 2014). Fludioxonil has a broad activity with a unique mode of action, which interferes with the life cycle of the fungus/oomycete i.e. spore germination, germ tube and mycelial growth (Syngenta 2014). Other studies have indicated that fludioxonil can also be effective when used in combination with mefenoxam against $R$. solani of soybean (Bucher and Pederson 2004; Lamprecht et al. 2011) and Fusarium spp. of maize (Munkvold and O'Mara 2002). In addition, fludioxonil was also found to be effective in reducing diseases caused by 
Phytophthora infestans on potatoes (Inglis et al. 1999), and against Pythium spp. and R. solani (Mazzola 1998).

\section{Conclusion}

The greenhouse experiment was carried out following positive promising results obtained during the in vitro experiment on the effectiveness of mefenoxam 350 gai/L, mefenoxam $240 \mathrm{~g}$ ai $\mathrm{L}^{-1}$ and fludioxonil $100 \mathrm{~g}$ ai $\mathrm{L}^{-1}$ against $R$. solani, $P$. ultimum and F. solani. During the greenhouse experiment, although all three fungicides reduced the percentage of diseased seedlings, and increased seedling emergence, plant height, dry shoot mass and dry root mass, none of them gave complete control of any of the diseases caused by the three pathogens under these trial conditions. Further research to test the effectiveness of these fungicides at different application times or their combination with other fungicides may provide improved results for the control of seed and soil-borne pathogens of cowpea.

Acknowledgements - We thank J. Boshoff Fourie for providing cultures; Syngenta SA for supplying chemicals and the National Research Foundation for financing the research. 


\section{References}

Augusto J, Brenneman TB, Csinos AS. 2010. Etiology of peanut pod rot in Nicaragua: II. The role of Pythium myriotylum as defined by applications of gypsum and fungicides. Online. Plant Health Progress.

Aveling TAS, Govender V, Kandolo DS, Kritzinger Q. 2012. The effects of treatments with selected pesticides on viability and vigour of maize (Zea mays) seeds and seedling emergence in the presence of Fusarium graminearum. Journal of Agricultural Science 151: 474-481.

BASF, 2014. http://agproducts.basf.us/products/stamina-fungicide-seedtreatment.html [Accessed on 23 June 2014].

Bucher ES, Pedersen WL. 2004. Evaluation of fludioxonil and azoxystrobirin for control of Rhizoctonia solani of soybean. Phytopathology 94: 2004-2075.

Chang KF, Hwang SF, Ahmed HU, Gossen BD, Turnbull GD, Strelkov SE. 2013. Management strategies to reduce losses caused by Fusarium seedling blight of field pea. Canadian Journal of Plant Science 93: 619-625. 
Errampalli D. 2004. Effect of fludioxonil on germination and growth of Penicillium expansum and decay in apples cvs. Empire and Gala. Crop Protection 23: 811817.

Fravel DR, Deahl KL, Stommel JR. 2005. Compatibility of the biocontrol fungus Fusarium oxysporum strain CS-20 with selected fungicides. Biological Control 34: 165-169.

Fuchs SJ, Himyck RE. 2000. Crop profile for dry peas in Idaho. Moscow: College of Agriculture, University of Idaho. pp 2-7.

Greencast 2014. http://www.greencast.com.au/products/subdue-maxx. [Accessed on 22 June 2014].

Inglis DA, Powelson ML, Dorrance AE. 1999. Effect of registered potato seed piece fungicides on tuber-borne Phytophthora infestans. Plant Disease 83: 229234.

King EB, Parke JL. 1993. Biocontrol of Aphanomyces root rot and Pythium damping-off by Pseudomonas cepacia AMMD on four pea cultivars. Plant Disease 77: 1185-1188. 
Kirk WW, Gachango E, Schafer R, Wharton PS. 2013. Effects of in-season cropprotection combined with postharvest applied fungicides on suppression of potato storage diseases caused by Fusarium pathogens. Crop Protection 57: 77-84.

Lamprecht SA, Tewoldemedhin YT, Calitz FJ, Mazzola M. 2011. Evaluation of strategies for the control of canola and lupin seedling diseases caused by Rhizoctonia anastomosis groups. European Journal of Plant Pathology 130: 427439.

Langyintuo AS, Lowenberg-Deboer J, Faye M, Lambert D, Ibro G, Moussa B, Kergna A, Kushwaha S, Musa S, Ntoukam G. 2003. Cowpea supply and demand in West and Central Africa. Field Crops Research 82: 215-231.

Martinez-Espinoza A, Mueller DS, Buck JW. 2004. Efficacy of fungicide for Rhizoctonia root rot control on Cathara roseus. Biological Sciences 94: 20042019.

Masangwa JIG, Aveling TAS, Kritzinger Q. 2013. Screening of plant extracts for antifungal activities against Colletotrichum species of common bean (Phaseolus vulgaris L.) and cowpea (Vigna unguiculata (L.) Walp). Journal of Agricultural Science 151(4): 482-491. 
Mazzola M. 1998. Elucidation of the microbial complex having a causal role in the development of apple replant disease in Washington. Phytopathology 88: 930938.

Munkvold GP, O'Mara JK. 2002. Laboratory and growth chamber evaluation of fungicidal seed treatments for maize seedling blight caused by Fusarium species. Plant Disease 86: 142-150.

McGovern RJ, Elmer WH, Geiser DM, Harbaugh BK. 2001. Biology, epidemiology, and integrated management of diseases caused by Fusarium. In: Potted ornamentals. Gainesville, United States of America: University of Florida Department of Plant Pathology.

McMullen MP, Bradley CA. 2005. Field crop fungicide guide. United States of America: North Dakota State University.

Nissen O. 1983. MASTAT-C: A microcomputer program for the design, management and analysis of agronomic research experiments. East Lansing: Michigan State University.

Singh SR, Rachie KO. 1985. Cowpea research, production and utilization. New York: John Wiley \& Sons. 
Solorzano CD, Malvick DK. 2011. Effects of fungicide seed treatments on germination, population and yield of maize grown from seed infected with fungal pathogens. Field Crops Research 122: 173-178.

Summerfield RJ, Roberts EH. 1985. Grain legume crops. London: Collins.

Syngenta. 2005. http://www.syngenta.com/en/productsservices/celest.html. [Accessed on 12 October 2005].

Syngenta. 2014. http://www.syngenta.com/global/corporate/en/products-andinnovation/product-brands/seed-care/Pages/celest.aspx [Accessed 22 June 2014].

Valenzuela H, Smith J. 2002. Cowpea. College of Tropical Agriculture and Human Resources, Honolulu. Hawaii: University of Hawaii at Monoa.

Wang H, Chang KF, Hwang SF, Turnbull GD, Howard RJ, Blade SF, Callan NW. 2005. Fusarium root rot of coneflower seedlings and integrated control using Trichoderma and fungicides. Biological Control 50: 317-329. 